\title{
Aboriginal Biocultural Knowledge in South-eastern Australia: Perspectives of Early Colonists. By Fred Cahir, lan D. Clark, and Philip A. Clarke. 2018. Csiro Publishing, Clayton, Australia. 334 pp.
}

\author{
Ingvar Svanberg ${ }^{1^{*}}$ \\ ${ }^{1}$ Institute for Russian and Eurasian Studies, Uppsala University, Uppsala, Sweden. \\ *ingvar.svanberg@ires.uu.se
}

Received June 14, 2020

Accepted November 11, 2020

Published January 8, 2021

DOI 10.14237/ebl.12.1.2021.1712

Copyright (c) 2021 by the author(s); licensee Society of Ethnobiology. This is an open-access article distributed under the terms of the Creative Commons Attribution-NonCommercial 4.0 International Public License (https://creativecommons.org/licenses/by-nc/4.0), which permits non-commercial use, distribution, and reproduction in any medium, provided the original author and source are credited.

This book immediately thrilled me. In recent years, I have devoted myself to researching the Lop people in the Tarim Basin, NW China, a group of formerly fisher-foragers that used to live in the desert area of Innermost Asia. In my research, I used historical data provided by various Western travelers to the region, but it has been difficult to obtain a more comprehensive picture about their environmental knowledge. For that reason, I am intrigued by this historical study of the biocultural knowledge of Aboriginal peoples in southeastern Australia as recorded by early European colonists. The book presents extensive data while also providing a broad picture of the hunter-forager cultures of colonial era South-eastern Australia.

Aboriginal Biocultural Knowledge demonstrates that historical research of hunter-forager cultures is possible, and that important data can be obtained from the sources compiled by early colonists and explorers. Indigenous voices are almost absent in this study. Nevertheless, the amount of information extracted from outsider sources is very rich.

Three of the authors are historians with extensive experience in source criticism, and the fourth is a social anthropologist-ethnoscientist. Through meticulous research, Fred Cahir (historian), Ian D. Clark (historian), Sarah McMaster (historian), and Philip A. Clarke (anthropologist and ethnobiologist) provide us with a detailed description of various aspects of Aboriginal life in south-eastern Australia. This is a biocultural region located south of Lower Murray, Riverland, Maillee and South East of South Australia, all of Victoria and southern New South
Wales. Various Aboriginal peoples and tribes lived and live in the area, including the Bangerang, Barrabool, Daungwurrung, Djadjawurrung, Gunditjmara, Gurngulag, Kurnai, and Wadawurrung. Many of the region's diverse languages are extinct or dormant today. After British settlement, much Indigenous knowledge was lost as Aboriginal peoples were forced to abandon their hunting and gathering lifeways. They were separated from their land when they had to live more restricted lives on mission reserves. Today, data about Indigenous knowledge are to be found in various archival materials, journals, dictionaries and unpublished reports. The sources used in this book are records from travelers or colonists who lived in the region before and during the early phases of European colonizing in the late eighteenth and early nineteenth century, and who interacted with the Australian Aboriginal communities.

Using multiple sources is an essential research method among ethnobiologists in order to find scattered information about historical activity contexts between humans and the biota. That is true for this publication-the authors seem to have made a great effort to use every source available on the topic.

Throughout the book's fifteen chapters, Indigenous Australians' past complex relationships with their environments, spiritual life, and biocultural knowledge is described and analyzed. The first chapter discusses totemic life, followed by chapters on terrestrial and water spirits. Five further chapters discuss means of subsistence and Aboriginal 
environmental understandings. Important are the chapters on plant food, animal food (birds, fish, invertebrates, and reptiles were important for these foragers), healing, and how the Aboriginal population satisfied material needs, such as clothing, housing, and transport. In an interesting chapter, the historian Sarah McMaster co-authored a piece about fire management practices. Other topics discussed in detail in the book are perceptions of time, knowledge about the skyworld, and seasonal calendars.

While the aim of each chapter is to summarize the ethnographic information available on each topic, the research also reveals historical evidence of the complex asymmetrical relationships between early European settlers and Aboriginal people. For example, it describes the implications of the interplay between Indigenous and European knowledge systems and how this affected and changed the relationship and lifestyles of both groups.
I would like to conclude this brief report by pointing out that it is rare for ethnobiologists to provide such an in-depth study extending beyond information about the use of food and medicine of animals and plants. I learned many interesting things about Aboriginal cultures and their interaction with the landscape and biota in Australia. I found the information about healing and traditional medicinal procedures derived from the historical sources valuable and fascinating. Likewise, the chapter on water is full of interesting details. I hope this study can serve as model for researchers in regions such as Europe and Inner Asia where historical research of this type could provide insights into the pre-industrial peasants' and nomads' biocultural knowledge, which is a relatively unexplored topic.

This book will be a useful reference for cultural ecologists, ethnobiologists, and anyone concerned with Australian history. 